\title{
SYED MUHAMMAD NAQUIB AL-ATTAS' IDEAS ON THE ISLAMIZATION OF KNOWLEDGE AND ITS RELEVANCE WITH ISLAMIC EDUCATION IN INDONESIA
}

\author{
Muhammad Kosim, Martin Kustati \& Murkilim \\ Universitas Islam Negeri Imam Bonjol \\ Jl. Mahmud Yunus Lubul Lintah, Padang, Sumatera Barat, 25153 \\ e-mail:muhammadkosim@uinib.ac.id, martinkustati@uinib.ac.id, murkilimtkhanif@gmail.com
}

\begin{abstract}
This article discusses on Syed Muhammad Naquib al-Attas's thoughts on the Islamization of Knowledge and analyzes its relevance to the development of Islamic education in Indonesia. A library research was employed by collecting relevant papers and writings. To interpret literatures, a hermeneutic approach was used where the data taken from content analysis. The study showed that the main thought of Naquib al-Attas was that all knowledge comes from Allah SWT. Meanwhile, the development of Western science tends to be secular. The Islamization of knowledge must be carried out in the Islamic education system by releasing knowledge from various interpretations based on secular ideology, meanings and expressions. The idea has relevance to the development of Islamic education as an effort to overcome the dichotomy paradigm of science in Indonesia.
\end{abstract}

\begin{abstract}
Abstrak: Artikel ini bertujuan untuk menguraikan pemikiran Syed Muhammad Naquib al-Attas tentang Islamisasi Ilmu Pengetahuan lalu menganalisis relevansinya dengan pengembangan pendidikan Islam di Indonesia. Jenis penelitian ini adalah library research dengan mengumpulkan karya tulis yang relevan untuk mencapai tujuan penelitian di atas. Untuk memahami, menafsirkan dan memaknai literatur teks, digunakan pendekatan hermeneutik. Sedangkan pengolahan dan penganalisaan semua data, digunakan metode content analysis. Artikel ini menemukan bahwa pemikiran utama Naquib al-Attas adalah semua ilmu berasal dari Allah SWT. Namun perkembangan ilmu pengetahuan Barat cenderung sekuler dan bebas nilai. Islamisasi ilmu pengetahuan mesti dilakukan dalam sistem pendidikan Islam dengan cara melepaskan ilmu pengetahuan dari berbagai interpretasi yang didasarkan pada ideologi, makna, dan ungkapan yang bersifat sekuler. Gagasan ini memiliki relevansi dengan perkembangan pendidikan Islam dalam upaya mengatasi paradigma dikotomi ilmu di Indonesia.
\end{abstract}

Keywords: Islamization of knowledge, al-Attas, Indonesia's Islamic education 


\section{Introduction}

On the basis of tauhid, the Prophet SAW. had succeeded in building a civil society in the city of Yathrib and inspiring the people in the afterlife so that the graphics of Muslim civilization continued to rise until the heyday of the 'Abbasid and the Umayyah-Andalusian daulah. However, after the collapse of the 'Abbasids and the Umayyad-Andalusians (especially Cordova and Seville) in the XIII century, Muslim civilization had experienced ups and downs. On the other hand, Western civilization which is considered to be stronger and more advanced has made other nations often orientated towards the West (western centric), including in the development of educational models and scientific studies. The existence of a paradigm illustrates that science in the west is more advanced and becomes the main reference for advancing a nation, including Indonesia, this has led to Western "cultural imperialism" as a center for the periphery areas. Meanwhile, Western countries actually have a dark history between the church vs the scientists, so that the ideology of secularism and liberalism of the church and scientists has the potential to emerge. Western civilization developed into a secular, pragmatic, and materialist and they are causing a new problem: a spiritual crisis. This phenomenon threatens the existence of a civilized society in its true meaning, e.g. a society that is rich in of good values, peaceful, and in true happiness.

Among the figures who were concerned of this phenomenon was Syed Muhammad Naquib al-Attas. Anxiety related to the civilization of the Ummah in facing the dangers of Western civilization sharpened his reasoning to find a solution: "Islamization of Science." Although this concept caused controversy among Muslim intellectuals, ${ }^{1}$ at least al-Attas has introduced the ideas that inspire many people to realize the fallacy of dichotomous, skeptical and materialist Western scientific epistemology and returns Islamic civilization to its original state, as exemplified by the Prophet Muhammad. Studies on the concept of Islamization of knowledge of Naquib al-Attas have been widely conducted. Irma Novayani, for example, examined the implications of the thought of Islamization of Ilmu al-Attas for the ISTAC educational institution she founded. ${ }^{2}$ Mauliyah focused on studying the Islamization of al-Attas' knowledge as a movement to overcome the dichotomy of science. ${ }^{3}$

${ }^{1}$ Hendriadi Hendriadi, "Posisi Pendidikan Agama dalam Sistem Pendidikan Nasional: Usaha Islamisasi Ilmu," in Al-Ihda': Jurnal Pendidikan Dan Pemikiran, Vol. XII, No. 1, 2017, p. 8.

${ }^{2}$ Irma Novayani, "Islamisasi Ilmu Pengetahuan Menurut Pandangan Syed M. Naquib Al-Attas dan Implikasi terhadap Lembaga Pendidikan International Institute of Islamic Thought Civilization (ISTAC)," in Jurnal Al-Mutaaliyah: Jurnal Pendidikan Guru Madrasah Ibtidaiyah, Vol. II, No. 1, 2017, p. 74.

${ }^{3}$ Anita Mauliyah, "Gerakan Islamisasi Ilmu Pengetahuan Naquib Al-Attas," in EL-BANAT: Jurnal Pemikiran dan Pendidikan Islam, Vol. VI, No. 1, 2017, p. 111; For discussion in a wider context see Mhd. Syahnan, "Islam as a System: A Critical Analysis of Sayyid Quthb's Principle Thought," in Analytica Islamica, Vol. 4 No. 1, 2002, 45-57. 
Meanwhile Ahmad Suyuthi discussed the urgency of the ta'dîb concept that al-Attas campaigned as an effort to Islamize knowledge to answer the crisis of knowledge. ${ }^{4}$

Unlike the previous researcher's studies, this article analyzes the concept of Islamization of knowledge of Naquib al-Attas as a solution to the problems of the Ummah that he formulated, then examines its relevance in overcoming the problems of Islamic education in Indonesia. Initial allegations, al-Attas' idea also has relevance to education in Indonesia, whether directly or indirectly, where the stretching of Islamic education development in breaking the dichotomy of science was felt after the discourse of "Islamization of knowledge" became "food of thought" among academics and education practitioners. Islam, especially in Indonesia.

\section{Methodology}

A library research was conducted which aimed to solve a problem. Basically, this research becomes one of types of qualitative research, because there is an interest in interpreting and seeking meanings from written texts. ${ }^{5}$ Library research directs research to examine and trace ideas and thoughts on literature sources such as manuscripts, written works and so on. Thus, to examine the thoughts of Syed Muhammad Naquib alAttas about the concepts of Islamization of science and its relevance to Islamic education in Indonesia, it was analyzed the written sources from relevance Syed Muhammad Naquib al-Attas works.

In understanding and interpreting literatures and texts, a hermeneutic approach was used. The urgency of the hermeneutic approach in research is an effort to understand the meaning of the texts under study to avoid distortion of messages or information between writer and reader in understanding the texts. In processing and analyzing all data from literatures and texts. ${ }^{6}$ The content analysis method was used to measure the level of accuracy and the process of drawing conclusions on messages. ${ }^{7}$ There were three steps that have been done, namely descriptive, critical content, and correlative analysis. ${ }^{8}$ The data was analyzed into three stages. First, data collection activities were taken from scientific study references either by Naquib al-Attas or other scientific works that related to his thoughts

${ }^{4}$ Abdur Razzaq, "Islamic Civilization of Malay: Histrorical Polemic and Modern Challenges (The Thought of Syed Naquib Al-Attas)," in Journal of Malay Islamic Studies, Vol. II, No. 2, 2018, p. 125.

${ }^{5}$ Bagong Suyanto dan Sutinah, Metode Penelitian Sosial: Berbagai Alternatif Pendekatan (Jakarta: Kencana, 2005), p. 186.

${ }^{6}$ Irman Suprayogo dan Tobroni, Metodologi Penelitian Sosial-Agama (Bandung: Remaja Rosdakarya, 2001), p. 73-75.

${ }^{7}$ Ibid., p. 134-136.

${ }^{8}$ Klans Purippendolf, Analisis Isi: Pengantar Teori dan Metodologi, tr. Farid Wadji (Jakarta: Rajawali, 1991), p. 15. 
on the Islamization of science which then classified and describe them Second, data analysis activities were performed after describing Naquib al-Attas' concepts of thinking about the Islamization of science, then analyzed using inductive, deductive, and interactive thinking patterns (a combination of inductive and deductive) to find the relevance of these thoughts to the implementation of Islamic education. Third, we provided interpretation and meaning of the results of the analysis which aimed to draw conclusions.

\section{Results and Discussion}

\section{The Figure of Syed Muhammad Naquib al-Attas}

His full name is Syed Muhammad Naquib al-Attas bin Ali bin Abdullah bin Muhsin bin Muhammad al-Attas (better known as "al-Attas"), born on September 5, 1931 in Bogor, West Java. ${ }^{9}$ Al-Attas was born to the couple Syed Ali al-Attas, a nobleman in Johor with Sharifah Raquan bint Syed Muhammad al-Aydarus, a descendant of a relative of the Sundanese kings in Sukapura, West Java. The lineage of his father, Syed Ali al-Attas, who comes from Arabia, is a descendant of well-known scholars and Sufis among Sayyids. ${ }^{10}$

Al-Attas moved to Malaysia when he was 5 years old with his parents and attended Ngee Heng Primary School until the age of 10. Then, al-Attas moved again to Indonesia and continued his education at 'Urwah al-Wusqa, Sukabumi for 5 years when Japan controlled Malaysia. In Sukabumi, the Naqsabandiyah tarekat developed so that al-Attas began to deepen the understanding of a strong Islamic tradition, including the tarekat. ${ }^{11}$ In 1946 he returned to Johor Baru and studied at Bukit Zahrah School then at English Johor Baru (1946-1949 AD). At that time, Malaysia was still under British rule, so that alAttas joined the Army Service to become a cadre officer in the Malay-British Army. He also attended military education and training at Eaton Hall, Chester, England, and continued at the Royal Military Academy Sandhurst England (1952-1959 AD) to occupy the rank of lieutenant. ${ }^{12}$

Al-Attas had a high enthusiasm for science so he left the Military Service. Then, alAttas continued his bachelor study in social sciences at the University of Malaya (19571959 AD). Al-Attas produced two works that are well known to date: Ruba'iyat (1959) and Some Aspects of Sufism as Understood and Practiced Among the Malays (1963). Through

9 Wan Mohd Nor Wan Daud, Filsafat dan Praktik Pendidikan Islam Syed M. Naquib alAttas, tr. Hamid Fahmy, et al. (Bandung: Mizan, 2003), p. 45.

${ }^{10}$ Wan Mohammad Daud noted that the lineage of the Naquib al-Attas family can be traced back thousands of years through the lineage of Sayyid in the Ba'lawi family in Hadramaut with the lineage that goes to Imam Husayn, the grandson of the Prophet Muhammad. Ibid.

${ }^{11}$ Al-Rasyidin dan Samsul Nizar, Filsafat Pendidikan Islam: Pendekatan Historis, Teoritis dan Praktis (Jakarta: Ciputat Press, 2005), p. 118.

${ }^{12}$ Kemas Badaruddin, Filsafat Pendidikan Islam: Analisis Pemikiran Prof. Dr. Syed Muhammad Naquib al-Attas (Yogyakarta: Pustaka Pelajar, 2007), p. 10. 
these two scientific works, Canada Council Fellowship gave him a scholarship to continue his Masters studies at the Institute of Islamic Studies, McGill University, Montreal. He has interacted with great figures such as Fazlur Rahman (Pakistan), Sir Hamilton Gibb (England), Toshihiko Izutsu (Japan), and Sayyed Hossein Nasr (Iran) at this University. ${ }^{13}$

In 1962, Naquib Al-Attas received his master degree of Magister of Arts at McGilll University in Montreal, Canada with a thesis entitled Raniry and the Wujudiyyah of 17th Century Acheh. Al-Attas continued his doctoral studies through the scholarsip of Sir Richard Winstert and Sir Morimer Wheeler from the British Academy at the School of Oriental and African Studies, University of London (1963-1964). Al-Attas obtained his Ph.D. (Philosophy Doctor) in Islamic philosophy and Islamic Malay literature through his tesis entitled The Mysticism of Hamzah Fanshuri under the guidance of Professor Martin Lings. ${ }^{14}$ After alAttas received his Ph.D. dgeree, he became a permanent lecturer at the University of Malaya, and served as Dean of the Faculty of Letters from 1968-1970. He is also one of the founding figures of the University Kebangsaan Malaysia (1970). ${ }^{15}$

Al-Attas has received various academic achievements. In addition to Professor of Malay Language and Literature who was inaugurated on January 24, 1972, he was later appointed as an International Member of the American Philosophical Association by American philosophers in 1970. Then, he became a scholar of the Iranian Maharaja Academy of Philosophy, a fellow of the Imperial Iranian Academy of Philosophy. This is the highest gift in the scientific field of the Iranian empire in 1975. His great ideas became increasingly recognized in the Islamic world when he presented his essay: "Preliminary Thought on The Nature of Knowledge and the Definition and Aims of Education" at the first ever world Islamic Conference conducted in 1977. He is also known as the Director of The Institute of Islamic Thought and Civilization (ISTAC), based in Malaysia (1988). ${ }^{16}$ As a prolific writer who has published 27 articles in several scientific seminars and 26 books he has written, including Islam and Secularism (1978), and Islam and the Philosophy of Science (1989). ${ }^{17}$

\section{The Problems of the Ummah}

Naquib al-Attas wrote about some of the problems experienced by the people that hindered the progress of their civilization. In my opinion, there are at least four issues that have received sharp criticism from Naquib al-Attas. The first criticism is the effect of secularization that is developing in the West. In the view of al-Attas, some Muslim scholars

\footnotetext{
${ }^{13}$ Daud, Filsafat dan Praktik Pendidikan Islam Syed M. Naquib al-Attas, p. 49.

${ }^{14}$ Ibid., p. 49-50.

${ }^{15}$ Badaruddin, Filsafat Pendidikan Islam, p. 11-12.

${ }^{16}$ Ibid., p. 12-13.

${ }^{17}$ Daud, Filsafat dan Praktik Pendidikan Islam Syed M. Naquib al-Attas, p. 55-56.
} 
and scholars have been influenced by Western views and fascinated by advances in science and technology, causing many mistakes among the ummah, especially in thinking. Muslims are faced with a process of secularization that is developing in the West. ${ }^{18}$ Secularization is the liberation of humans from the confines of religion and metaphysics that govern their reason and language. The main dimensions of secularization are: " 1 ) the disenchantment of nature in the sense of separating nature from the religious dimension; 2) the elimination of the sanctity and authority of religion from politics (desacralization of politics); and 3) the elimination of the sanctity and absoluteness of religious values from life (deconsecratioan of values)."19

The second criticism has to do with the West's conflict with Islam. Al-Attas believes that muslims are not only faced with internal problems in the form of dim intellectual passion, but also the confrontation that has occurred in the history of Western culture and civilization against Islam. The root of the problem of confrontation cannot be separated from Christian groups as an important part of Western civilization. Christianity has the potential and ability to become a universal religion that will rule over nations and world affairs. In contrast to other religions that are limited to one location or national in nature, such as Judaism and Zoroaster, or their teaching principles do not have a rescue mission such as Hinduism and Buddhism. With the exception of Islam, since the beginning of its arrival Islam has challenged Christianity's right to universality. Even Islam questions the authenticity and truth of Christian doctrine, as implied in the letter al-Ikhlas. Especially in its history, Islamic civilization dominated the world economy in the 9th to 14th centuries forcing the West to live in isolation and then looking for other ways to get international sources of supplies. In this search, including the encouragement of Islamic civilization in Andalusia, after the Reconquista in the 15th and 16th centuries, the West appeared again to dominate the world history stage and at the same time, Muslims suffered a decline. Since the 17th century, Western nations have controlled important areas in the Muslim world so that indirectly it also has implications for changes in the culture and thoughts of the people through the education system..$^{20}$

Al-Attas also emphasized that "the West will always see Islam as a true rival in the world; as the only eternal force that opposes it, and which challenges its belief and its fundamental principles." ${ }^{21}$ However, the ability of the West to colonize muslims is also because of the weakness of muslims themselves. Western culture has attacked the hearts of the ummah by "cutting off muslims from mastery of Islamic science and of course this implies that slowly Western culture has entered the learning system so that it can slowly

${ }^{18}$ Syed M. Naquib al-Attas, Islam dan Sekularisme, tr. Khalif Muammar, second edition (Bandung: Institut Pemikiran Islam dan Pembangunan Insan [PIMPIN], 2011), p. 18-19.

${ }^{19}$ Ibid., p. 20.

${ }^{20}$ Al-Attas, Islam dan Sekularisme, p. 119-128.

${ }^{21}$ Ibid., p. 128. 
replace the Islamic system so that the relationship of Islamic culture among muslims is cut off." 22

The third criticism relates to the loss of adab (manner). This is an internal problem of the ummah who loses the disciplines of body, mind and soul so that they are unable to recognize and play a role in their relationship with themselves, society and their followers due to errors in knowledge and then cause people to lose adab. As a result, leaders emerged who were not worthy of legitimate leadership for Muslims, did not have the high moral, intellectual and spiritual level required by Islam. ${ }^{23}$ Its main characteristic is "the process of leveling everyone in thoughts and attitudes at the same level." As a result, people who actually have glory are put at a low level, including reviling pious people, scholars, and high knowledge. Al-Attas said:

None of the so-called modernists and reformers of our time, including those who masquerade as 'ulama', have come close to reaching the lowest level of the great scholars of the past and people of spiritual wisdom who have contributed greatly to Islamic knowledge and wordviews, both in the form of intelligence, intellect and spiritual knowledge, as well as in the form of numerous analyzes, interpretations, original self-commentaries and written efforts. In fact they have never produced works like that, most of their writings are journalistic in nature and content. ${ }^{24}$

The fourth criticism relates to the westernization of science (knowledge). Al-Attas argues that when muslims are faced with the challenges of knowledge spread by Western civilization throughout the world. In this condition, the science that they have developed and spread has brought chaos to human life because it causes confusion and skepticism. For them, doubt and conjecture are the most precise epistemological means of reaching the truth. In fact, the nature of science is not neutral, because it is influenced by intellectual views and psychological perceptions of a civilization. According to al-Attas, Western civilization is "a civilization that developed from the historical amalgamation of ancient Greek and Roman cultures, philosophies, values and aspirations, its union with Judaism and Christianity, and the further development and formation of Latin, Germanic people, Celtic and Nordic." 25 Thus, Western countries do not make revelation and religion the source of truth and reality, but instead refer to cultural traditions and human thoughts that are merely speculation in secular thought, patterns, and behavior. Humans are seen from the physical and rational animal dimensions (hayawân al-nâthiq). "Absolute values are rejected, while relative values are firmly held; nothing is certain except the certainty

${ }^{22}$ Syed M. Naquib al-Attas, Risalah untuk Kaum Muslimin (Kuala Lumpur: ISTAC, 2001), p. 47.

${ }^{23}$ Al-Attas, Islam dan Sekularisme, p. 129-130.

${ }^{24}$ Ibid. p. 137.

${ }^{25}$ Ibid. p. 166. 
that nothing is certain." ${ }^{26}$ Finally, the knowledge that was developed denied Allah and the Judgement Day. Although Christianity has religious dogma, it is in conflict with Western academics. ${ }^{27}$ Ironically, the westernization of knowledge has hit some muslim scholars, as previously explained.

\section{Islamization of Knowledge as a Solution}

According to Wan Mohd. Nor Wan Daud, there are three scientific findings produced by al-Attas that have the potential to influence the lives of Muslims entering the 15th/21st century AD. The scientific work, first is related to the problem of science among Muslims. The second finding is that modern science is not value-free (neutral) because it is influenced by Western culture. The third finding relates to the importance of the Islamization of science. ${ }^{28}$ In this finding, al-Attas put forward the meaning of Islamization and Islamization of science as a solution to the various problems of muslims, especially those related to education and civilization.

Islamization is "human liberation that begins with liberation from traditions that contain elements of magic, mythology, animism, nationalism-culture that are contrary to Islam and then liberation from secular confinement of reason and language." Islamization is a process that is more devolutionary in its original state than evolution in which man as a spirit is already perfect, but when human is incarnated in the body one will become negligent, ignorant and zhâlim towards himself so that it is inevitable that he becomes imperfect." ${ }^{29}$ This is the essence of humans who are born with natural potential.

In the context of Islamic education, every human being is born with a natural nature. While humans remain in their nature, they will become perfect humans (al-insân alkâmil). If not, according to the author, humans will be despised so that their dignity resembles an animal (Q.S. al-A'râf/7: 176 and 179; al-Mâ'idah/5: 60; al-Ankabût/29: 41; al-Jumû'ah/ 62: 5); or inanimate objects such as stones (al-Baqarah/2: 74). In order for humans to remain in their nature and their sacred basic potentials to develop optimally, it takes a tarbiyah wa talîm or a planned and sustainable educational process in accordance with Islamic guidance. The devolutionary Islamization offered by al-Attas is essentially in line with the essence of Islamic education which seeks to educate people to remain in their nature and spiritual purity.

Al-Attas also emphasized that in an individual sense, Islamization refers to the Prophet Muhammad SAW. as the highest and most perfect example. In a collective, social

${ }^{26}$ Ibid. p. 169.

${ }^{27}$ Ifa Afida, "Pemikiran Tokoh Islamisasi Ilmu Pengetahuan: (Syed Muhammad Naquib Al-Attas)," in FALASIFA: Jurnal Studi Keislaman, Vol. VII. No. 2, 2017, p. 286.

${ }^{28}$ Daud, Filsafat dan Praktik Pendidikan Islam Syed M. Naquib al-Attas, p. 317.

${ }^{29}$ Al-Attas, Islam dan Sekularisme, p. 54-55. 
and historical sense, Islamization refers to "the struggle of a community towards the attainment of moral and ethical qualities as part of the social excellence that was achieved during the time of the Prophet SAW. under the guidance of Allah SWT." ${ }^{30} \mathrm{Al}$-Attas stated that the Islamization began with the Islamization of language through the Qur'an when it was first revealed to Arabs. The Islamization of language causes the Islamization of thought and reason, so that secular beliefs, thoughts and behavior will not occur. Thus, Islamization is also an attempt to ward off and stop westernization. ${ }^{31}$

Furthermore, the idea of Islamization was developed in science. The Islamization of science is related to "the liberation of science from interpretation or interpretation based on ideology, meanings and expressions of secular people."'32 This is important, considering the science developing in the West is influenced by their secular culture and civilization, minus transcendental-axiologies and ignoring the divine dimension. As a result, the science that develops in the West keeps people from their nature as religious creatures.

Strictly speaking, the concept of Islamization of knowledge offered by al-Attas emphasizes that every knowledge possessed brings humans closer to Allah SWT. Because all knowledge comes from Him..$^{33}$ There are two kinds of knowledge which constitute a perfect unity: first, al-ilm or al-ma'rifah as true knowledge given by Allah SWT. to humans in two realities: as tanzil and as an introduction that refers to oneself and realm and God. As tanzil it is called al-ilm, which is actual knowledge. He is the main knowledge as guidance to direct people to the straight path. While the introduction (ma'rifah), obtained by humans by conducting acts of worship as an effort to define oneself so that Allah SWT. gives him the knowledge. ${ }^{34}$ The holy Qur'an, sunnah, sharia, al-ilm al-ladunniy, and wisdom are the main elements of this first kind of knowledge. Especially regarding wisdom - including the ma'rifah category - obtained by carrying out the commands of Allah SWT. by increasing the deeds of worship to Him. This ma'rifah will be obtained by humans through direct inspiration given by Allah SWT. or through spiritual enjoyment ( $d z a w q)$ and disclosure of spiritual visions (kashf). To obtain this knowledge, every muslim must have knowledge of prerequisites which include knowledge of the basics of Islam (Islam, faith and ih $\underline{h} s a n$ ), its principles, meanings and meanings, as well as understanding and correct implementation in daily life and practice. Second, 'ilm (plural 'ulûm) which means knowledge that is

${ }^{30}$ Al-Attas, Islam dan Sekularisme, p. 56.

${ }^{31}$ Mujadad Zaman and Nadeem A Memon, "An Olive Tree in the Apple Orchard: Establishing an Islamic College in the United States," in Philosophies of Islamic Education (Routledge, 2016), p. 134.

${ }^{32}$ Syed M. Naquib al-Attas, Konsep Pendidikan dalam Islam, $3^{\text {th }}$ edition (Bandung: Mizan, 1988), p. 90

${ }^{33}$ Al-Attas, Islam dan Sekularisme, p. 179.

${ }^{34}$ Syed Muhammad Naquib al-Attas, Islam dan Filsafat Sains (Bandung: Mizan, 1995), p. 78-79. 
pursued by humans. This knowledge is obtained by humans based on their own 'aqliah effort through experience, observation and research. These are the sciences ('ulûm). ${ }^{35}$

According to al-Attas, both knowledge must be obtained by humans through conscious actions ("amal). So the "prerequisite knowledge" to obtain the first knowledge becomes the obligation of every Muslim (fardh 'ain), while others become fardh kifâyah. Knowledge that is fardh 'ain is the basic foundation for various types of knowledge on this earth. Without the guidance of the first science, the second science will not be able to guide humans to truth and justice. ${ }^{36}$ On the other hand, if the first science underlies the second science, then the second science becomes "true knowledge" or the knowledge that is in accordance with nature. ${ }^{37}$

With the concept above, it is clear that Islam is a teaching that encourages its people to master and develop knowledge. It is the role of this knowledge that becomes the capital of the people to form a civilization. During the time of Rasulullah SAW., for example, the command of 'iqra in the Mecca period encouraged people to love and develop knowledge, especially the Umayyad and Abbasid eras. Likewise, when Islam entered Indonesia, the Islamic trend which encouraged the development of science made this religion easily accepted by local people. Al-Attas wrote, "The arrival of Islam in the MalayIndonesian Archipelago characterized a new era in its history which firmly brought rationalism and knowledge of 'aqliah and emphasized a social system based on individual freedom, justice and the dignity of human personality." 38

The Islamization of science emphasizes the importance of developing knowledge as the "essence of science" discussed above. The efforts to Islamize science are carried out in two stages. First, alienating the main elements and concepts of a science in the mold of Western culture as opposed to Islam, especially those related to the humanities (humanities), in addition to the natural knowledge (science) and other applied sciencesin particular which deals with the interpretation of facts and the formulation of theorieswhich are actually part of the human sciences. ${ }^{39}$

${ }^{35}$ Al-Attas, Islam dan Sekularisme, p. 181-182.

${ }^{36}$ Ibid., p. 183-184. The conception of knowledge in the category of fardh 'ain and fardh kifayah seems to be influenced by Imam al-Ghazâlî's view. However, al-Ghazâlî classifies knowledge into two categories of al-'ulum al-syar'iyyah and ghairu al-syar'iyyah. The first category fardh 'ain while the second fardh kifayah, when this knowledge is needed for fulfilling such worldly affairs as medicine, calculus, and the like. Imam al-Ghazâlî, Ihyâ' 'Ulûmiddîn, tr. Mop. Zuhri, Jilid I, 30 ${ }^{\text {th }}$ edition (Semarang: CV Asy-Syifa', 2009), p. 53. See also Mhd. Syahnan, "The Image of the Prophet and the Systematization of Ushul al-Fiqh: A Study of al-Shafi'i's Risalah", in Miqot, No. 103, 1998, pp. 44-50.

${ }^{37}$ Al-Attas, Islam dan Sekularisme, p. 201.

${ }^{38}$ Syed Muhammad Naquib al-Attas, Islam dalam Sejarah dan Kebudayaan Melayu (Kuala Lumpur: Petaling Jaya, Angkatan Belia Islam Malaysia [ABIM], 1990), p. 2.

${ }^{39}$ Al-Attas, Islam dan Sekularisme, p. 200-201. 
Second, after going through the first process, the knowledge will be filled with elements and basic Islamic concepts that are in accordance with their nature. This means that it is not just "inclusion" or "transferring" of science and Islamic principles, but also must remove foreign elements and diseases or neutralize them before the body of knowledge is reformed based on Islamic teachings. Then, the next action is to "formulate and combine Islamic elements and main key concepts to produce core knowledge and then place it in the Islamic education system, from elementary to high level. It needs to be designed in stages to suit the stages of each level." 40

The core knowledge at the university level, for example, "knowledge developed in principle must be related to the nature of man (insân), the nature of religion (dîn) and human involvement in it, knowledge ('ilm and ma'rifah), wisdom (wisdom), and justice ('adl). This of course should relate to humans and their religion, as well as the nature of true charity ('amal-adab)." ${ }^{41}$ Everything must refer to the concept of God (tawhîd), revelation (the holy book of the Qur'an), its meaning and message, the revealed law (syarî'ah) with all the guidance exemplified by Rasulullah SAW. in his sunnah, as well as the history and messages of the previous prophets. In addition, it is also necessary to refer to the science of Islamic principles and practice, religious sciences (al-ulûm al-syar'iyyah) which include the valid elements of Sufism and Islamic philosophy. Likewise, Arabic knowledge and Islamic word view in depth. The primary and secondary levels need to be adjusted in a simpler form. According to al-Attas, "the core knowledge must be formed uniformly to be applied in the education system for Muslim communities around the world, therefore this knowledge is mandatory for every Muslim (fardh 'ain)." ${ }^{42}$

Meanwhile, science which is a fardh kifâyah must be filled with foreign key elements/ concepts that have been alienated from each of its branches, it must be accompanied by knowledge of history, culture and civilization, Islamic thought, and the development of science in Islam. According to him, it is necessary to formulate a subject on the comparison of religion from the perspective of Islam and Western culture so that Muslims understand their culture and civilization so that there is a harmonization between the core sciences and the sciences. ${ }^{43}$

So, the Islamization of science must be carried out in the Islamic education system. If the Islamization of science is successful, education can form a civilized ummah. In this context, Naquib al-Attas emphasized the importance of education which aims to form a "good human being." The most important element in the concept of Islamic education is the cultivation of adab, which encapsulates the spiritual and material life of humans to

${ }^{40}$ Ibid., p. 201-202.

${ }^{41}$ For more detail on al-Attas's key concepts see his Risalah untuk Kaum Muslimin (Kuala Lumpur: ISTAC, 2001).

${ }^{42}$ Al-Attas, Islam dan Sekularisme, p. 201

${ }^{43}$ Ibid. 
cultivate good qualities. ${ }^{44} \mathrm{Al}$-Attas also argued that adab is a "discipline of body, soul and spirit" which reflects justice and wisdom (wisdom), includes material and spiritual life, and includes charity and knowledge. So in education a harmonious combination of knowledge, charity and manners is formed. Referring to the notion of adab, al-Attas defines education as "recognition and recognition which is gradually implanted in humans relating to the appropriate places for everything in the order of existence. Of course, this leads to knowing and acknowledging God's proper place in that order of existence." ${ }^{45} \mathrm{Al}$ Attas's emphasis on adab and emphasizes the proper term education is ta'dîb, showing that the essential purpose of education is to form human beings who have adab. ${ }^{46}$ This is the main asset in shaping the civilization of the people which is based on divine and human values and develops optimally and in balance, between body and spirit, as well as knowledge, charity, and morals.

\section{The Relevance of the Islamization of Knowledge with the Development of Islamic Education in Indonesia}

The idea of the Islamization of science was not only put forward by Al-Attas, but was supported and developed by other figures, such as Ismail Raji al-Faruqi and Seyyed Hossein Nasr. ${ }^{47}$ However, there are also groups that criticize this idea. They believe that when we see it from a historical point of view, the science and technology that developed in the West today were inspired by Muslim intellectuals, especially in the "golden age of Islam." Because we don't need to be suspicious of the current development of science in the West. Science and technology is considered neutral, depending on who brings and uses it. So the Islamization of subjects or tenants and science and technology developers is more important than just the discourse of Islamization of science. ${ }^{48}$

Apart from the pros and cons of the Islamization of science, it seems that this idea has had a positive impact on Muslims to develop an ideal Islamic education, including in Indonesia. The dualism of education that has resulted in the dichotomy of knowledge

${ }^{44}$ Ibid., p. 187.

${ }^{45}$ Al-Attas, Konsep Pendidikan dalam Islam, p. 52-62.

${ }^{46}$ Farah Ahmed, "An Exploration of Naquib Al-Attas' Theory of Islamic Education as Ta'dîb as an "Indigenous" Educational Philosophy," in Educational Philosophy and Theory, Vol. L, No. 8, 2017, p. 8.

${ }^{47}$ Yasir Hussain, "The Works and Contributions of Ismai'il Raji Al-Faruqi in Islamization of Knowledge," in Journal of Islamic Thought and Civilization (JITC), Vol. V, No. 1, 2017, p. 25; Abdullatif Ahmadi Ramchahi, et al., "Seyyed Hossein Nasr's Perspective on the Theory of Islamization of Knowledge," in International Journal of Contemporary Applied Sciences, Vol. III, No. 5, 2017, p. 28.

${ }^{48}$ Muhaimin, Nuansa Baru Pendidikan Islam: Mengurai Benang Kusut Dunia Pendidikan (Jakarta: RajaGrafindo Persada, 2006), p. 43. 
has long been felt by Muslims in Indonesia. ${ }^{49}$ Pesantren as an Islamic educational institution focuses more on the study of tafaqquh fi al-dîn, while the schools introduced by the Dutch colonialist only teach science. This dichotomy impression is also inseparable from the influence of education developed by the West with a secular scientific style, as much criticized by Naquib al-Attas.

The leaders of Islamic education at the beginning of the twentieth century had realized the dangers it would pose so that among them established educational institutions that combined religious and general sciences to avoid a dichotomy of knowledge. Call it Dr. Abdullah Ahmad, in 1907 founded the Adabiah School in Padang with a classical pattern and studied religion and general sciences. Or Zainuddin Labay founded Diniyah School in 1915 and Rahmah Yunisiyah founded Diniyah Putri in 1923 in Padang Panjang by designing Vocational Modern Education. ${ }^{50}$

After the independence of the Republic of Indonesia, a national education system was formed. In the history of its journey, national education still accommodates Islamic education with its religious sciences in public schools which were previously considered secular schools. The issuance of the Joint Regulation of the Minister of Education, Teaching and Culture with the Minister of Religion No. 1142/Bh. A (Teaching) dated 2-12-1946 and No. 1285/K.J (Religion) dated 12-12-1946 established the teaching of Religion in low schools since grade IV and became effective on January 1, 1947. This was the beginning of the policy of teaching religion into schools. Furthermore, madrasas also include general subjects, even the Ministerial Decree 3 of 1975 emphasizes that madrasas make Islamic religious subjects as basic subjects that are published at least $30 \%$ in addition to general subjects. That means, there will be madrasas that carry out 70\% general knowledge and 30\% religious knowledge. Moreover, with the presence of Law Number 20 of 2003 concerning the National Education System and Government Regulation Number 55 of 2007 concerning Religious and Religious Education, the position of religious education is getting stronger in formal education institutions: schools and madrasas.

However, it cannot be denied that the national education system that organizes schools and madrasas can create a dichotomy paradigm of knowledge so that the behavior that appears contradicts one another. Those who master the science of religion do not understand the development of science and technology so that their space is limited only to religious issues. On the other hand, those who master general science are less concerned with the problems of Muslims, or even their behavior does not reflect a Muslim. As a result, the problems of the Muslim community are often borne by the "ulama" or the madrasa/

${ }^{49}$ Muhammad Kosim, "Pendidikan Agamais-Nasionalis untuk Keutuhan NKRI," in H.A.R. Tilaar, Tinjauan secara Kritis Reformasi Pendidikan Nasional (Jakarta: Media Indonesia Publishing, 2017), p. 192.

${ }^{50}$ Rini Rahman, "Modernisasi Pendidikan Islam Awal Abad 20 (Studi Kasus Di Sumatera Barat)," in Humanus, Vol. XIV. No. 2, 2017, p. 177. 
pesantren circles. Even though every Muslim should have the same responsibility to present themselves as the best people. Of course, this phenomenon arises from an understanding of secular science, knowledge that is not linked to the principles and basis of tawhîd.

For this case, Naquib al-Attas's criticism of the science that developed in the West with the influence of culture and civilization has a point and feels real in Indonesia. AlAttas also mentioned that "the pedagogical relationship between the Qur'an and the various local languages of Muslims has been severed at low levels of education among traditional Muslims. in its place are secular, national, ethnic and traditional schools emphasized. Whereas at the higher education level, the study of language and culture has been carried out using linguistic and anthropological methodologies, meanwhile, literature and Islamic history studies using Western values and models, the framework of orientalist and philological studies and secularized social sciences, such as sociology, psychology, including educational theory." 51

Therefore, the emergence of the idea of the Islamization of science, especially since the first Islamic Education Conference in Mecca 1977, has become a hot topic of discussion among Muslim academics in Indonesia, because of its relevance to the historical development of Islamic education in this Muslim-majority country. Although there has been no indepth research study on the influence of the idea of Islamization of knowledge Naquib al-Attas along with other figures with the development of Islamic education in Indonesia at the end of the twentieth century until now, at least the idea has inspired and strengthened the Indonesian Muslims to find a model of an Islamic education system that is ideal, nondichotomic, and in accordance with the philosophy of science in an Islamic perspective.

Not satisfied with the pattern of schools that are closer to secular-even though there are religious subjects but general subjects are more dominant and tend to be separated from religious values-and the pattern of madrasas that are less than optimal in providing Islamic education, alternative educational institutions that combine schools and madrasah, namely Integrated Islamic Schools (IT) in various regions. Even at the tertiary level, there was a conversion from STAIN or IAIN to UIN. Especially for the last case, although it does not use the term "Islamization of knowledge", it substantially has the same idea, namely an awareness of the nature of knowledge - both religious and general knowledge - which actually comes from Allah and must be used according to His commands. UIN Syarif Hidayatullah Jakarta carries the term "integration of science and religion," by reintegrating scientific epistemology so that there is no dichotomy between general sciences and religious sciences. UIN Sunan Kalijaga Yogyakarta introduced the term "integrativeinterconnective approach" by interconnecting the hadhârah nash, hadhârah al-ilm, and hadhârah al-falsafah. ${ }^{52}$ Meanwhile, UIN Malang presents the term "tree of knowledge"

${ }^{51}$ Daud, Filsafat dan Praktik Pendidikan Islam Syed M. Naquib al-Attas, p. 334.

${ }^{52}$ Parluhutan Siregar, "Integrasi Ilmu-Ilmu Keislaman Dalam Perspektif M. Amin Abdullah," in Miqot: Jurnal Ilmu-Ilmu Keislaman, Vol. XXXVIII. No. 2, 2014, p. 335. 
which integrates various knowledge, some from the roots, stems, branches, twigs to leaves. Then the fruit of the tree is the result of graduates, namely people who are faithful, knowledgeable, do good deeds and have noble morals. ${ }^{53}$ However, the terms used seem still conceptual in nature, while the practical and technical-operational arrangements need development so that they become a model for application in Islamic educational institutions.

In terms of subjects, there have also been several attempts to combine science and religion, so that dichotomic and secular sciences do not occur anymore. In 1997, a collaboration was held between the Department of Religion and the Ministry of Education and Culture and the MAFIKIBB Development Agency (Mathematics, Physics, Chemistry, Biology and English) ICMI to deepen the insights and ideas of Islamic nuances and scientific concepts in general textbooks. Then a Teacher Manual on General Subjects with Islamic nuances was compiled with a process skills approach in madrasas-madarasah. ${ }^{54}$ In 1999, the Ministry of National Education also published "Manuscripts on the Relationship of 11 Subjects in Junior and Senior High Schools integrated with Imtaq" as part of the Project for Increasing Teachers' Religious Insights. In this manuscript, several verses of the Qur'an are presented that are relevant to the topic of discussion in each general subject. ${ }^{55}$ In other terms, this program is called "Integrated with Imtaq and Science and Technology".

Muslims, especially academics, must not stop doing studies to find and develop a model of Islamic education that is able to answer the challenges of the ummah, including as stated by al-Attas in this paper. The basic education of Muslims must choose schools that teach the sciences that are classified as fardh 'ain to instill tawhîd. ${ }^{56}$ If in college, they may develop a branch of science that is fardh kifâyah, with the hope that the knowledge they master is still based on tauhid. Of course, the Quran becomes the basic material that must be mastered, not only reading and writing, but preparing a generation of Muslims who love the Quran with endless studies to practice it as well as inspire to develop knowledge that is useful for building the civilization of the people.

\section{Conclusion}

The "Islamization of Knowledge" is one of the many thoughts of Syed Muhammad

\footnotetext{
${ }^{53}$ Mohammad Muslih, "Dinamika Pengembangan Ilmu di UIN Malang dan UIN Yogyakarta," in Kalimah: Jurnal Studi Agama dan Pemikiran Islam, Vol. XVII, No. 1, 2017, p. 29.

${ }^{54}$ Direktorat Jenderal Pembinaan Kelembagaan Agama Islam, Departemen Agama RI, Buku Pedoman Guru Madrasah Tsanawiyah Bernuansa Islam dengan Pendekatan Keterampilan Proses (Jakarta: Depag RI, 1997/1998).

${ }^{55}$ Direktorat Jenderal Pendidikan Dasar dan Menengah, Departeman Pendidikan Nasional, Naskah Keterkaitan 11 Mata Pelajaran di SLTP dengan Imtaq (Jakarta: Depdikbud RI, 2001).

${ }^{56} \mathrm{Al}$-Attas juga menegaskan bahwa konsep ilmu prasyarat (fardh 'ain) harus menjadi asas dan teras bagi semua pendidikan. Al-Attas, Islam dan Sekularisme, p. 193.
} 
Naquib al-Attas related to education. The idea of the Islamization of science is interesting to study and develop because the arguments it presents are widely felt by Muslims, especially Western hegemony, which in many ways - especially culture and beliefs - are not in accordance with muslims culture. Although the idea of Islamization of al-Attas' science is still general, this idea can inspire generations of Muslims, especially academics, to find a more appropriate and effective model according to conditions and needs. This model can be in formal education institutions from elementary to tertiary level, or in curriculum development, whether related to the material, methodology, or culture developed in the local educational institution. Thus, the idea of the Islamization of science has relevance to the development of Islamic education in Indonesia in an effort to overcome the dichotomy paradigm of science. Although he does not mention the term Islamization of science, the effort to overcome the dichotomy of science is actually relevant to Naquib al-Attas's offer.

\section{References}

Afida, Ifa. "Pemikiran Tokoh Islamisasi Ilmu Pengetahuan: (Syed Muhammad Naquib Al-Attas)," in FALASIFA: Jurnal Studi Keislaman, Vol. VII. No. 2, 2017.

Ahmed, Farah. "An Exploration of Naquib Al-Attas' Theory of Islamic Education as Ta'dîb as an "Indigenous" Educational Philosophy," in Educational Philosophy and Theory, Vol. L, No. 8, 2017.

Al-Attas, Syed Muhammad Naquib. Konsep Pendidikan dalam Islam, $3^{\text {th }}$ edition. Bandung: Mizan, 1988.

Al-Attas, Syed Muhammad Naquib. Risalah untuk Kaum Muslimin. Kuala Lumpur: ISTAC, 2001.

Al-Attas, Syed Muhammad Naquib. Islam dalam Sejarah dan Kebudayaan Melayu, $4^{\text {th }}$ edition. Kuala Lumpur: Petaling Jaya, Angkatan Belia Islam Malaysia [ABIM], 1990.

Al-Attas, Syed Muhammad Naquib. Islam dan Filsafat Sains. Bandung: Mizan, 1995.

Al-Attas, Syed Muhammad Naquib. Islam dan Sekularisme, tr. Khalif Muammar, second edition. Bandung: Institut Pemikiran Islam dan Pembangunan Insan [PIMPIN], 2011.

Al-Attas, Syed Muhammad Naquib. Risalah untuk Kaum Muslimin. Kuala Lumpur: ISTAC, 2001.

Asril, Asril. "Fitrah Manusia dan Pendidikan Islam (Perspektif Filsafat Pendidikan Islam)," in At-Ta'lim: Media Informasi Pendidikan Islam, Vol. XVI, No. 2, 2017.

Azra, Azyumardi. Pendidikan Islam: Tradisi dan Modernisasi Menuju Milenium Baru. Jakarta: Logos Wacana Ilmu, 1999.

Badaruddin, Kemas. Filsafat Pendidikan Islam: Analisis Pemikiran Prof. Dr. Syed Muhammad Naquib al-Attas. Yogyakarta: Pustaka Pelajar, 2007.

Daud, Wan Mohd Nor Wan. Filsafat dan Praktik Pendidikan Islam Syed M. Naquib alAttas, tr. Hamid Fahmy, et al. Bandung: Mizan, 2003. 
MIQOT Vol. 44 No. 2 July-December 2020

Direktorat Jenderal Pembinaan Kelembagaan Agama Islam, Departemen Agama RI. Buku Pedoman Guru Madrasah Tsanawiyah Bernuansa Islam dengan Pendekatan Keterampilan Proses. Jakarta: Depag RI, 1997/1998.

Direktorat Jenderal Pendidikan Dasar dan Menengah, Departeman Pendidikan Nasional. Naskah Keterkaitan 11 Mata Pelajaran di SLTP dengan Imtaq. Jakarta: Depdikbud RI, 2001.

Al-Ghazâlî, Imam. Ihya' 'Ulumiddin, tr. Moh. Zuhri, Jilid I, 30 ${ }^{\text {th }}$ edition. Semarang: CV Asy-Syifa', 2009.

Hadi, Hasbullah. "Kebijakan Pendidikan Nasional Terhadap Pendidikan Islam dan Pendidikan Sekuler," in MIQOT: Jurnal Ilmu-Ilmu Keislaman, Vol. XL, No. 2, 2016.

Hendriadi, Hendriadi. "Posisi Pendidikan Agama dalam Sistem Pendidikan Nasional: Usaha Islamisasi Ilmu," in Al-Ihda': Jurnal Pendidikan dan Pemikiran, Vol. XII, No. 1, 2017.

Hussain, Yasir. "The Works and Contributions of Ismai'il Raji Al-Faruqi in Islamization of Knowledge," in Journal of Islamic Thought and Civilization (JITC), Vol. V, No. 1, 2017.

Kosim, Muhammad. "Pendidikan Agamais-Nasionalis untuk Keutuhan NKRI," in H.A.R. Tilaar, Tinjauan secara Kritis Reformasi Pendidikan Nasional. Jakarta: Media Indonesia Publishing, 2017.

Mauliyah, Anita. "Gerakan Islamisasi Ilmu Pengetahuan Naquib Al-Attas," in EL-BANAT: Jurnal Pemikiran dan Pendidikan Islam, Vol. VI, No. 1, 2017.

Mualimin, Mualimin. "Lembaga Pendidikan Islam Terpadu," in Al-Tadzkiyyah: Jurnal Pendidikan Islam, Vol. VIII. No. 1, 2017.

Mudzakir, Mudzakir. "Peran Epistemologi Ilmu Pengetahuan dalam Membangun Peradaban," in Kalimah: Jurnal Studi Agama Dan Pemikiran Islam, Vol. XIV. No. 2, 2017.

Muhaimin. Nuansa Baru Pendidikan Islam: Mengurai Benang Kusut Dunia Pendidikan. Jakarta: RajaGrafindo Persada, 2006.

Muslih, Mohammad. "Dinamika Pengembangan Ilmu di UIN Malang dan UIN Yogyakarta," in Kalimah: Jurnal Studi Agama dan Pemikiran Islam, Vol. XVII, No. 1, 2017.

Nata, Abuddin et al. Integrasi Ilmu Agama dan Ilmu Umum. Jakarta: RajaGrafindo Persada, 2005.

Novayani, Irma. "Islamisasi Ilmu Pengetahuan Menurut Pandangan Syed M. Naquib AlAttas dan Implikasi terhadap Lembaga Pendidikan International Institute of Islamic Thought Civilization (ISTAC)," in Jurnal Al-Mutaaliyah: Jurnal Pendidikan Guru Madrasah Ibtidaiyah, Vol. II, No. 1, 2017.

Purippendolf, Klans, Analisis Isi: Pengantar Teori dan Metodologi, tr. Farid Wadji. Jakarta: Rajawali, 1991.

Rahman, Rini. "Modernisasi Pendidikan Islam Awal Abad 20 (Studi Kasus di Sumatera Barat)," in Humanus, Vol. XIV. No. 2, 2017. 
Ramchahi, Abdullatif Ahmadi et al. "Seyyed Hossein Nasr's Perspective on the Theory of Islamization of Knowledge," in International Journal of Contemporary Applied Sciences, Vol. III, No. 5, 2017.

Al-Rasyidin and Samsul Nizar. Filsafat Pendidikan Islam, Pendekatan Historis, Teoritis dan Praktis, second edition. Jakarta: Ciputat Press, 2005.

Razzaq, Abdur. "Islamic Civilization Of Malay: Histrorical Polemic and Modern Challenges (The Thought Of Syed Naquib Al-Attas)," in Journal of Malay Islamic Studies, Vol. II, No. 2, 2018.

Saridjo, Marwan. Pendidikan Islam dari Masa ke Masa: Tinjauan Kebijakan Publik terhadap Pendidikan Islam di Indonesia. Bogor: Yayasan Ngali Aksara dan al-Manar Press, 2011.

Siregar, Parluhutan. "Integrasi Ilmu-Ilmu Keislaman Dalam Perspektif M. Amin Abdullah," in Miqot: Jurnal Ilmu-Ilmu Keislaman, Vol. XXXVIII. No. 2, 2014.

Suprayogo, Irman dan Tobroni, Metodologi Penelitian Sosial-Agama. Bandung: Remaja Rosdakarya, 2001.

Suyanto, Bagong dan Sutinah, Metode Penelitian Sosial: Berbagai Alternatif Pendekatan. Jakarta: Kencana, 2005.

Syahnan, Mhd. "The Image of the Prophet and the Systematization of Ushul al-Fiqh: A Study of al-Shafi'i's Risalah," in Miqot, No. 103, 1998.

Syahnan, Mhd. "Islam as a System: A Critical Analysis of Sayyid Quthb's Principle Thought," in Analytica Islamica, Vol. 4 No. 1, May 2002.

Zaman, Mujadad and Nadeem A Memon. "An Olive Tree in the Apple Orchard: Establishing an Islamic College in the United States," in Philosophies of Islamic Education, Routledge, 2016. 